\title{
PENGARUH KEPEMIMPINAN DAN SARANA PRASARANA OLAHRAGA TERHADAP PRESTASI SEKOLAH DI BIDANG OLAHRAGA
}

\author{
Inggri Andrea Fraliantina \\ STKIP Muhammadiyah Kuningan \\ email: andrea fraliantina@gmail.com
}

\begin{abstract}
Abstrak
Penelitian ini merumuskan tentang seberapa besar pengaruh kepemimpinan kepala sekolah terhadap prestasi sekolah di bidang olahraga? Seberapa besar pengaruh sarana dan prasarana olahraga terhadap prestasi sekolah di bidang olahraga? Seberapa besar pengaruh kepemimpinan kepala sekolah dan sarana prasarana pendidikan olahraga secara bersamasama terhadap prestasi sekolah di bidang olahraga?. Tujuan penelitian ini untuk menganalisis pengaruh kepemimpinan kepala sekolah terhadap prestasi sekolah di bidang olahraga, menganalisis pengaruh sarana dan prasarana olahraga terhadap prestasi sekolah di bidang olahraga, menganalisis pengaruh kepemimpinan kepala sekolah dan sarana prasarana pendidikan olahraga secara bersama-sama terhadap prestasi sekolah di bidang olahraga. Hasil penelitian: kepemimpinan kepala sekolah berpengaruh signifikan terhadap prestasi sekolah di bidang olahraga, sarana dan prasarana pendidikan olahraga berpengaruh signifikan terhadap prestasi sekolah di bidang olahraga, dan kepemimpinan kepala sekolah dan sarana prasarana pendidikan olahraga secara bersama-sama berpengaruh signifikan terhadap prestasi sekolah di bidang olahraga.
\end{abstract}

Kata Kunci: Kepala Sekolah, Sarana, Prasarana, Prestasi Sekolah

\begin{abstract}
This research formulates how much influence the principal's leadership has on school performance in the sport? How much influence do sports facilities and infrastructure have on school performance in the sport? How big is the influence of the leadership of the principal and the infrastructure of sports education together on the achievements of the school in the sports field? The purpose of this study was to analyze the influence of principals' leadership on school performance in the field of sports, analyze the influence of sports facilities and infrastructure on school performance in the field of sports, analyze the influence of leadership of school principals and infrastructure for sports education together on school performance in the sport. The results: Principal leadership has a significant effect on school performance in the field of sports, sports education facilities and infrastructure have a significant effect on school performance in the field of sports, and the leadership of school principals and infrastructure for sports education together have a significant effect on school performance in the sport.
\end{abstract}

Keywords: Principal, Facilities, Infrastructure, School Achievement. 
PENDAHULUAN

Dalam suatu organisasi selalu melibatkan beberapa orang yang saling berinteraksi secara intensif. Interaksi tersebut disusun dalam suatu struktur yang dapat membantu dalam usaha pencapaian tujuan bersama. Agar pelaksanaan kerja dalam organisasi dapat berjalan sebagaimana mestinya maka dibutuhkan sumber seperti perlengkapan, metode kerja, bahan baku, dan lain-lain. Usaha untuk mengatur dan mengarahkan sumber daya ini disebut dengan manajemen. Sedangkan inti dari manajemen adalah kepemimpinan (leadership).

Konsep tentang kepemimpinan kepala sekolah tidak dapat dilepaskan dari konsep kepemimpinan secara umum. Kegiatan kepemimpinan harus diselenggarakan oleh seseorang yang menduduki posisi atau jabatan tertentu yang dilingkungannya terdapat sejumlah orang yang harus bekerja sama untuk mencapai tujuan.

Kepala sekolah memiliki pengaruh positif terhadap kualitas praktik pengajaran dan pencapaian belajar peserta didik di sekolah. Kepala sekolah melaksanakan fungsi kepemimpinan, yang melibatkan pendidik dan tenaga kependidikan lainnya, dalam rangka memetakan arah pendidikan sekolah di masa yang akan datang, mengembangkan pencapaian kualitas sekolah yang diharapkan, memelihara fokus perhatian terhadap proses pengajaran dan pembelajaran yang efektif, serta membangun lingkungan belajar yang kondusif untuk menghasilkan peserta didik yang unggul.

Kepemimpinan kepala sekolah menjadi faktor penentu dalam proses pendidikan yang berlangsung di sekolah. Kepemimpinan pendidikan memang bukan hanya diperankan oleh kepala sekolah. Peran besar pendidikan akan terwujud apabila ada kerja sama kepemimpinan di tiap tingkatan pengambil kebijakan (Menteri, Dirjen, Kepala Dinas dan stakeholders lainnya), sehingga dapat memfokuskan pada upaya bagaimana mencapai hasil belajar yang optimal bagi peserta didik.

Sesuai dengan uraian tersebut, Wahjosumidjo (1999) dalam Imam (2012:14) menjelaskan, bahwa "Secara sederhana kepala sekolah dapat didefinisikan sebagai seorang tenaga fungsional guru yang diberi tugas untuk memimpin suatu sekolah di mana diselenggarakan proses belajar, mengajar atau tempat di mana terjadi interaksi antara guru yang memberi pelajaran dan murid yang menerima pembelajaran."

Dalam hal ini kepala sekolah bertugas melaksanakan fungsi kepemimpinan, baik fungsi yang berhubungan dengan pencapaian tujuan pendidikan maupun penciptaan iklim sekolah yang kondusif bagi terlaksananya proses belajar mengajar secara efektif dan 
efisien. Kepala sekolah yang berhasil apabila memahami keberadaan sekolah sebagai organisasi yang kompleks dan unik, dan mampu melaksanakan peranan kepada sekolah sebagai seorang yang diberi tanggung jawab untuk memimpin sekolah.Berdasarkan penjelasan tersebut, Imam (2012:15) menjelaskan, bahwa "Kepemimpinan kepala sekolah adalah kemampuan menggerakkan semua personal satuan pendidikan atau sekolah dalam melaksanakan tugas pembelajaran sesuai dengan frinsip pedagodik atau tindakan (tingkah laku) diantara individu dan kelompok yang menyebabkan mereka bergerak kearah tercapainya tujuan pendidikan yang menambah penerimaan bersama bagi mereka."

Selain itu, sekolah merupakan sebuah sistem, tepatnya sistem pendidikan. Pemerintah telah berusaha melakukan pembaruan pada kurikulum pendidikan, pembaruan ini melahirkan Kurikulum Tingkat Satuan Pendidikan (KTSP) yang menjadi pedoman dalam penyelengaraan kegiatan pembelajaran, khususnya pada pembelajaran Pendidikan Jasmani. Dalam upaya merealisasikan KTSP yang telah dikembangkan oleh pemerintah dan menyelenggarakan pembelajaran PENJAS yang efektif, maka sekolah harus memiliki sarana dan prasaran yang cukup dan memadai serta mempunyai standar kualitas yang baik. Sarana dan prasarana yang dimaksud disini adalah berupa lapangan, bola, serta peralatan atau perlengkapan olahraga lainnya.

Keberadaan sarana dan prasarana tersebut dapat mempermudah guru dalam proses belajar mengajar penjas, sehingga dapat mengembangkan pengetahuan, daya cipta, jasmani dan rohani, dan juga disiplin siswanya. Keberadaan sarana dan prasarana disekolah harus dirawat dengan baik dan disimpan ditempat yang baik pula, agar kualitas dari sarana dan prasarana tersebut tetapa terjaga.

$$
\text { Dengan adanya sarana dan }
$$
prasarana ini sangat menunjang akan terlaksananya pendidikan di sekolah tersebut, Depdiknas (2008:37) dalam Barnawi dan M. Arifin (2012:47-48) menjelaskan, bahwa "Sarana pendidikan adalah semua perangkat peralatan danperabot yang secara langsung digunakan dalam proses pendidikan di sekolah. Sedangkan "Prasarana Pendidikan adalah semua perangkat kelengkapan dasar yang secara tidak langsung menunjang pelaksanaan proses pendidikan di sekolah."

Begitu juga dengan standar sarana dan prasarana, Donni dan Rismi (2014:27) menjelaskan, bahwa Standar sarana dan prasarana adalah standar nasional pendidikan yang berkaitan dengan kriteria minimal tentang ruang belajar, tempat berolahraga, tempat beribadah, perpustakaan, laboratorium, bengkel kerja, tempat bemain, tempat berkreasi dan berekreasi, serta sumber belajar lain yang 
diperlukan untuk menunjang proses pembelajaran, termasuk penggunaan teknologi informasi dan komunikasi.

$$
\text { Dengan demikian jika }
$$

kepemimpinan kepala sekolah, sarana dan prasarananya sudah cukup baik maka hasilnya pun akan baik, seperti yang akan diteliti sekarang, adanya pengaruh antara kepemimpinan kepala sekolah, sarana dan prasarana terhadap prestasi sekolah dalam bidang olahraga di SD Negeri UPTD PAUD PNFI TK dan SD Kecamatan Jatinunggal Kabupaten Sumedang.

Banyak orang yang mengejar prestasi di segala bidang, mereka menilai kemampuan seseorang dari piala, penghargaan atas prestasi yang telah diraihnya.. tapi apakah kita sudah mengerti apa sebenarnya hakikat dari pengertian prestasi itu sendiri, jika kita membahas tentang pengertian prestasi maka banyak orang yang mengemukakan pendapatnya tentang prengertian prestasi, baik dalam bidang belajar atau bidang lain.

Haryanto (2010) dalam Admin (29 Oktober 2014)mengungkapkan, bahwa "Prestasi belajar adalah hasil yang dicapai oleh seseorang setelah ia melakukan perubahan belajar, baik di sekolah maupun di luar sekolah." Sedangkan menurut Winkel, (2002:45) dalam admin (7 Maret 2014) "Prestasi adalah bukti keberhasilan usaha yang dapat dicapai."

Saya selaku peneliti ingin mengetahui pengaruh apa saja yang dihasilkan oleh kepemimpinan kepala sekolah, sarana dan prasarana olahraga terhadap prestasi sekolah di bidang olahraga itu sendiri. Karena masih banyak sekolah yang belum memiliki sarana dan prasarana olahraga yang memadai, khususnya di seluruh SD Negeri di UPTD PAUD PNFI TK dan SD Kecamatan Jatinunggal Kabupaten Sumedang. Dengan adanya penelitian ini saya selaku peneliti berharap bisa memberikan manfaat-manfaat tentang konsep kepemimpinan kepala sekolah dan sarana prasarana olahraga itu sangat penting bagi prestasi sekolah di bidang olahraga.

\section{METODE}

Dalam suatu rangkaian penelitian tidak akan terlepas dari metode yang digunakan, hal ini terkait dengan keberhasilan yang ingin dicapai dengan menentukan metode yang tepat sesuai dengan masalah yang diteliti. Sesuai dengan tujuan tersebut, maka metode penelitian yang digunakan dalam penelitian ini adalah metode penelitian kuantitatif.

Untuk mengungkap fakta pada saat terkini, sehingga menekankan pada fenomena objek yang dikaji secara deskriptif dan mendeskripsikan fenomena tersebut apa adanya. Menurut Sugiyono (2012:14) "Metode kuantitatif adalah metode yang berlandaskan pada filsafat positifisme, digunakan untuk meneliti pada populasi atau sampel tertentu, teknik pengambilan sampel pada umumnya 
dilakukan secara analisis data bersifat kuantitatif/statistik dengan tujuan untuk menguji hipotesis yang telah ditetapkan."

Waktu penelitian ini adalah pada bulan April 2015 sampai dengan bulan Mei 2015, sedangkan untuk tempat penelitian ini adalah seluruh Sekolah Dasar Negeri yang ada di UPTD PAUD PNFI TK dan SD Kecamatan Jatinunggal Kabupaten Sumedang. Objek dalam penelitian ini adalah tentang kepemimpinan kepala sekolah, sarana dan prasarana, prestasi sekolah dalam bidang olahraga. Yang peneliti jadikan responden dan sumber informasi tentang data yang akan diteliti adalah seluruh guru PJOK dan kepala sekolah SD Negeri yang ada di lingkungan UPTD PAUD PNFI TK dan SD Kecamatan Jatinunggal Kabupaten Sumedang, begitu juga dengan tempat penelitiannya adalah seluruh Sekolah Dasar Negeri yang ada di lingkungan UPTD PAUD PNFI TK dan SD Kecamatan Jatinunggal Kabupaten Sumedang.

Dalam mendukung tercapainya tujuan penelitian yang penulis lakukan, peranan populasi dan sampel sangat diperlukan untuk memperoleh sumber data. Suharsimi (2006:130) menjelaskan, bahwa "Populasi adalah keseluruhan objek penelitian." Sedangkan menurut Sugiyono (2013:117) menjelaskan "Populasi adalah wilayah generalisasi yang terdiri atas objek/subjek yang mempunyai kualitas dan karakteristik tertentu yang ditetapkan oleh peneliti untuk dipelajari dan kemudian ditarik kesimpulannya." Berdasarkan pengertian di atas peneliti menentukan populasi dalam penelitian ini adalah seluruh kepala sekolah dan guru PJOK SD Negeri yang ada di lingkungan UPTD PAUD PNFI TK dan SD Kecamatan Jatinunggal Kabupaten Sumedang, kepala sekolah berjumlah 26 orang dari 28 Sekolah dasar karena ada 4 sekolah yang dipegang oleh 2 kepala sekolah dan guru PJOK 28 dari 28 Sekolah Dasar Negeri.

Sedangkan untuk sampelnya, penulis mengambil seluruh dari populasi sehingga disebut penelitian populasi. Sugiyono (2013:118) mengemukakan, bahwa "Sampel adalah bagian dari jumlah dan karakteristik yang dimiliki oleh populasi tersebut." Sedangkan Suharsimi (2006:131) menjelaskan, bahwa "Sampel adalah sebagian atau wakil populasi yang diteliti." Jumlah sampel yang akan digunakan yaitu sebanyak dari jumlah populasi karena mengacu pada pendapat Suharsimi (2006:134) yang menjelaskan “Apabila subjeknya kurang dari 100, maka lebih baik diambil semua sehingga penelitiannya merupakan penelitian populasi. Tetapi, jika jumlah subjeknya besar, dapat diambil 10$15 \%$ atau $20-25 \%$ atau lebih." Sehingga dapat disimpulkan, sampel pada penelitian ini adalah keseluruhan dari populasi, yaitu seluruh kepala sekolah dan guru PJOK yang ada di lingkungan UPTD PAUD PNFI 
TK dan SD Kecamatan Jatinunggal Kabupaten Sumedang.

Menurut Nazir (2011:99) dalam Enjang (2014:61), bahwa "Desain penelitian adalah proses yang diperlukan dalam pelaksanaan penelitian, mulai dari identifikasi dan pemilihan masalah, sampling, analisis data, interprestasi data dan generalisasi serta pelaporan hasil penelitian." Begitu juga dengan Kerlinger dalam Tomi (2012:84) menjelaskan, bahwa
"Penelitian survey adalah penelitian yang dilakukan pada populasi besar maupun kecil, tetapi data yang dipelajari adalah data dari sampel yang diambil dari populasi tersebut, sehingga ditemukan relative, distributisi, dan hubungan antar variabel sosiologis maupun psikologis." Hubungan antar variabel-variabel yang terlibat dalam penelitian ini dapat dijelaskan sebagai berikut.

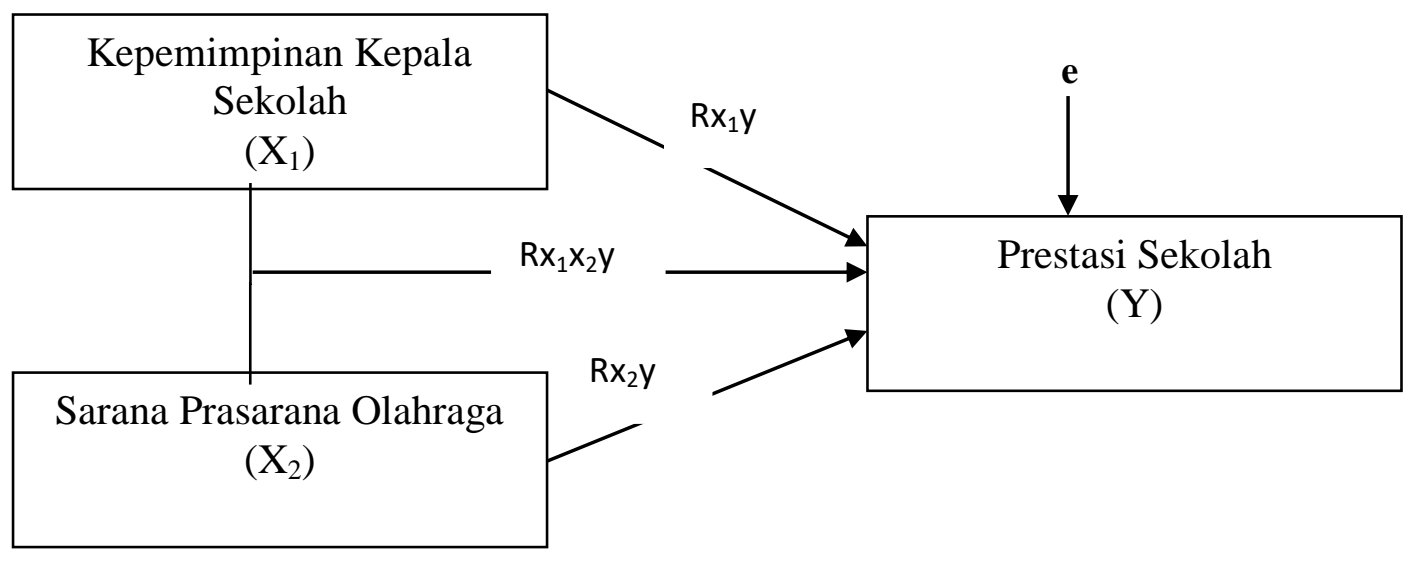

Sugiyono, (2013:219)

\section{HASIL PENELITIAN}

Pengaruh Kepemimpinan Kepala Sekolah terhadap Prestasi Sekolah di Bidang Olahraga. Pengaruh antara variabel Kepemimpinan Kepala Sekolah $\left(\mathrm{X}_{1}\right)$ terhadap Prestasi Sekolahdi Bidang Olahraga (Y) yang dihitung dengan koefisien korelasi adalah 0,767 atau $\left(\mathrm{r}_{\mathrm{X} 1 \mathrm{Y}}=\right.$ 0,767). Hal ini menunjukkan pengaruh yang tinggi di antara Kepemimpinan Kepala Sekolah terhadap Prestasi Sekolah. Untuk menyatakan besar kecilnya pengaruh (sum- bangan) variabel $\mathrm{X}_{1}$ terhadap $\mathrm{Y}$ atau koefisien diterminan $=\mathrm{r}^{2} \times 100 \%$ atau $0,767^{2} \times 100 \%=58,83 \%$. Kemudian untuk mengetahui tingkat signifikan koefisien korelasi $\mathrm{X}_{1}$ terhadap $\mathrm{Y}$ dengan metode dua pihak (2-tailed) dari output (diukur dari probabilitas) menghasilkan angka 0,000. Karena probabilitas jauh di bawah 0,05, maka pengaruh antara Kepemimpinan Kepala Sekolah terhadap Prestasi Sekolah adalah signifikan. 
Artinya Pengaruh kepemimpinan kepala sekolah sangat penting bagi prestasi sekolah di bidang olahraga atau prestasi sekolah memiliki ketergantungan terhadap kepemimpinan kepala sekolah, seperti yang dikatakan Nawawi (1980) dalam Imam (2012:13) menjelaskan,

bahwa

"Kepemimpinan adalah kemampuan menggerakan, memberikan motivasi dan mempengaruhi orang-orang agar besedia melakukan tindakan-tindakan yang terarah pada pencapaian tujian melalui keberanian mengambil keputusan tentang kegiatan yang dilakukan."

Begitu juga dengan hasil-hasil penelitian terdahulu, Adam Samsu dalam Tesisnya yang berjudul "Pengaruh Kepemimpinan Kepala Sekolah dan Kesejahteraan Guru terhadap Kinerja Guru", dengan hasil penelitiannya Kepemimpinan kepala sekolah berpengaruh positif dan signifikan terhadap kinerja guru, dan Dadi Daryadi dalam Tesisnya yang berjudul "Pengaruh Kepemimpinan Kepala Sekolah dan Sarana Belajar terhadap Kinerja Guru" dengan hasil penelitiannya Kepemimpinan kepala sekolah berpengaruh positif terhadap kinerja guru, pada tingkatan yang sangat signifikan. Hal ini menunjukan bahwa kinerja guru memiliki ketergantungan terhadap kepemimpinan kepala sekolah sebesar nilai pengaruhnya. Sehingga dapat ditafsirkan bahwa kepemimpinan kepala sekolah berubah maka kinerja juga akan berubah.
Pengaruh Sarana dan Prasarana Pendidikan Olahraga terhadap Prestasi Sekolah di Bidang Olahraga. Pengaruh antara variabel Sarana dan Prasarana pendidikan olahraga $\left(\mathrm{X}_{2}\right)$ terhadap Prestasi Sekolah di Bidang Olahraga (Y) yang dihitung dengan koefisien korelasi adalah 0,615 atau $\left(r_{X 2 Y}=0,615\right)$. Hal ini menunjukkan pengaruh yang tinggi diantara Sarana dan Prasarana Pendidikan Olahraga terhadap Prestasi Sekolah di Bidang Olahraga. Sedangkan untuk menyatakan besar kecilnya pengaruh (sumbangan) variabel $\mathrm{X}_{2}$ terhadap $\mathrm{Y}$ atau koefisien diterminan $=r^{2} \times 100 \%$ atau $0,615^{2} \times 100 \%$ $=37,82 \%$. Kemudian untuk mengetahui tingkat signifikan koefisien korelasi $\mathrm{X}_{2}$ terhadap Y dengan metode dua pihak (2tailed) dari output (diukur dari probabilitas) menghasilkan angka 0,000 . Karena probabilitas jauh di bawah 0,05, maka pengaruh antara Sarana dan Prasarana Pendidikan Olahraga terhadap Prestasi Sekolah di Bidang Olahraga adalah signifikan.

Artinya prestasi sekolah di bidang olahraga sangat ketergantungan pada sarana dan prasarana pendidikan olahraga, Pengertian sarana dan prasarana menurut BNSP yaitu: "Sarana adalah perlengkapan pembelajaran yang dapat dipindah-pindah, dan Prasarana adalah fasilitas dasar untuk menjalankan fungsi sekolah/madrasah".

Prinsip-prinsip manajemen sarana prasarana pendidikan, dalam mengelola 
sarana dan prasarana pendidikan, terdapat beberapa prinsip yang perlu diperhatikan agar tujuan bisa tercapai dengan maksimal. Prinsip-prinsip tersebut menurut Bafadal (2003) dalam Admin (10 Juli 2015) adalah :

a) Prinsip pencapaian tujuan, yaitu sarana dan prasarana pendidikan di sekolah harus selalu dalam kondisi siap pakai apabila akan didaya gunakan oleh personil sekolah dalam rangka pencapaian tujuan pembelajaran di sekolah.

b) Prinsip efisiensi, yaitu pengadaan sarana dan prasarana di sekolah harus dilakukan melalui perencanaan yang seksama, sehingga dapat diakdakan sarana dan prasarana pendidikan yang baik dengan harga yang murah. Demikian juga pemakaiannya harus dengan hati-hati sehingga mengurangi pemborosan.

c) Prinsip administratif, yaitu manajemen sarana dan prasarana pendidikan di sekolah harus selalu memperhatikan UU, peraturan, instruksi, dan petunjuk teknis yang diberlakukan oleh pihak yang berwenang.

d) Prinsip kejelasan tanggung jawab, yaitu manajemen sarana dan prasarana pendidikan di sekolah harus didelegasika kepada personel sekolah yang mampu bertanggung jawab, apabila melibatkan banyak personil sekolah dalam manajemennya, maka perlu adanya deskripsi tugas dan tanggung jawab yang jelas untuk tiap personil sekolah. e) Prinsip kekohesifan, yaitu manajemen sarana dan prasarana pendidikan di sekolah harus direalisasikan dalam bentuk proses kerja sekolah yang sangat kompak.

Pengaruh Kepemimpinan Kepala Sekolah Sarana dan Prasarana Pendidikan Olahraga terhadap Prestasi Sekolah di Bidang Olahraga. Pengaruh Kepemimpinan kepala sekolah dan sarana prasarana pendidikan olahraga secara simultan terhadap prestasi sekolah di bidang olahraga yang dihitung dengan koefisien korelasi adalah 0,778 atau $\left(R_{x 1 \times 2}=0,778\right)$ hal ini menunjukkan pengaruh dalam katagori tinggi. Sedangkan pengaruh secara simultan variabel $\mathrm{X}_{1}$ dan $\mathrm{X}_{2}$ terhadap $\mathrm{Y}=$ $\mathrm{R}^{2} \times 100 \%$ atau $0,778^{2} \times 100 \%=60,53 \%$ sedangkan sisanya 39,47 \% ditentukan oleh variabel lain, seperti keterampilan guru PJOK, kemampuan guru PJOK, disiplin guru PJOK, komunikasi guru PJOK dan psikologi guru PJOK. Kemudian untuk mengetahui tingkat signifikan koefisien korelasi ganda terlihat pada Tabel 4.55 Anova $^{\mathrm{b}}$ antara variabel kepemimpinan kepala sekolah dan sarana prasarana pendidikan olahraga terhadap prestasi sekolah di bidang olahraga dengan menggunakan metode dua pihak (2-tailed) dari output (diukur dari probabilitas) menghasilkan angka sig $0,000^{\mathrm{b}}$. Karena probabilitas jauh dibawah 0,05 , maka pengaruh kepemimpinan kepala sekolah dan sarana prasarana pendidikan olahraga 
secara simultan terhadap prestasi sekolah di bidang olahraga adalah signifikan.

Artinya prestasi sekolah di bidang olahraga sangat ketergantungan terhapap dua variabel yaitu kepemimpinan kepala sekolah dan sarana prasarana pendidikan olahraga, seperti hasil penelitian Dadi Daryadi dalam Tesisnya yang berjudul "Pengaruh Kepemimpinan Kepala Sekolah dan Sarana Belajar terhadap Kinerja Guru, yaitu Kepemimpinan kepala sekolah dan sarana belajar berpengaruh positif terhadap kinerja guru, pada tingkatan yang sangat signifikan. Hal ini menunjukan bahwa kinerja guru memiliki ketergantungan terhadap kepemimpinan kepemimpinan kepala sekolah dan sarana belajar sebesar nilai pengaruhnya. Sehingga dapat ditafsirkan bahwa kepemimpinan kepala sekolah dan sarana belajar berubah maka kinerja guru juga akan berubah.

\section{SIMPULAN}

Berdasarkan hasil penelitian dan analisis data yang telah dilakukan, maka peneliti dapat mengambil kesimpulan bahwa Kepemimpinan Kepala Sekolah $\left(X_{1}\right)$ terhadap Prestasi Sekolahdi Bidang Olahraga (Y) berpengaruh positif dan signifikan dengan pernyataan, $\mathrm{F}$ hitung $>\mathrm{F}$ tabel, atau 77,196 > 19,470 maka Ho ditolak dan Ha diterima sehingga kepemimpinan kepala sekolah berpengaruh signifikan terhadap prestasi sekolah di bidang olahraga. Sarana dan Prasarana Pendidikan Olahraga $\left(\mathrm{X}_{2}\right)$ terhadap Prestasi Sekolahdi
Bidang Olahraga (Y) berpengaruh positif dan signifikan, dengan pernyataan, $\mathrm{F}_{\text {hitung }}>$ $F_{\text {tabel, }}$ atau 32,809>19,470 maka Ho ditolak dan $\mathrm{Ha}$ diterima sehingga sarana dan prasarana pendidikan olahraga berpengaruh signifikan terhadap prestasi sekolah di bidang olahraga. Kepemimpinan Kepala Sekolah (X1) dan Sarana Prasarana Pendidikan Olahraga (X2) terhadap Prestasi Sekolah di Bidang Olahraga (Y) berpengaruh positif dan signifikan, dengan pernyataan, $\mathrm{F}_{\text {hitung }}>\mathrm{F}_{\text {tabel, }}$ atau 40,659 $>$ 19,470 maka Ho ditolak dan Ha diterima sehingga kepemimpinan kepala sekolah dan sarana prasarana pendidikan olahraga secara bersama-sama berpengaruh signifikan terhadap prestasi sekolah di bidang olahraga.

\section{DAFTAR PUSTAKA}

Barnawi dan M. Arifin. (2012). Manajemen Sarana dan Prasarana Sekolah. Jogjakarta: Ar-Ruzz Media.

Djibran, A. (2016). Strategi Pemimpin Dalam Penguatan Iklim Sekolah Berbasis Multiple Intelligence. JUARA : Jurnal Olahraga, 1(1), 1527. Retrieved from http://jurnal.upmk.ac.id/index.php/ju $\underline{\operatorname{ara} / \text { article/view/55 }}$

Juni, Priansa Donni dan Somad, Rismi. (2014). Manajemen Supervisi dan Kepemimpinan Kepala sekolah. Bandung: Alfabeta.

Haryanto. (2010). Pengertian Prestasi Belajar [online]. Tersedia: http: 
I/belajar psikologi. com /pengertian-prestasibelajar[29 Oktober 2014]

Juliansyah, Tomi. (2012). Pengatuh Kinerja guru penjas dan fasilitas olahraga terhadap mutu lulusan siswa dalam pembelajaran penjas. Usul Penelitian. Universitas galuh. Tidak dipublikasikan.

Makalah olahrga [online]. Tersedia: http: l/judul makalah olahraga .blogspot. com/2012/04/sarana-danprasana.html[30 Oktober 2014]

Prestasi Sekolah [online] tersedia: http: //ade suherman. blogspot. com/2011/10/ prestasi-sekolah. html
Priantini, Inta Ratna. (2014). Pengaruh Manajemen Sarana dan Prasarana Olahraga dan Kompetensi Guru terhadap Kualitas Pembelajaran Penjas.Tesis. Universitas Galuh. Tidak dipublikasikan.

Sopian, Enjang. (2014). Pengaruh Manajemen Fasilitas dan Kompetensi Guru terhadap Prestasi Belajar Peserta Didik. Tesis. Universitas Galuh. Tidak dipublikasikan.

Wahyudi, Imam. (2012). Pengembangan Pendidikan. Jakarta: PT. Prestasi Pustakarya. 